\title{
Energy or nitrogen supply to sheep fed Acacia cyanophylla Lindl. leaves-based diets : effects on intake and digestion
}

\author{
H Ben Salem 1, A Nefzaoui 1, H Abdouli 2, L Ben Salem ${ }^{3}$ \\ IINRA de Tunisie, Laboratoire de Nutrition Animale, rue Hédi Karray, 2049 Ariana ; \\ 2Ecole Supérieure d'Agriculture de Mateur, 7049 Mateur ; \\ 3Office de l'Elevage et des Pâturages, rue Alain Savary, 1002 Tunis, Tunisia
}

Recent works done in our laboratory showed that the nutritive value of Acacia cyanophylla Lindl. leaves is low. High content of condensed tannins in acacia ( 3 to $7 \%$ ) seems to be the causative factor.

In this paper, we report preliminary results of a study dealing with the effect of energy (spineless cactus) or nitrogen (urea) supply on intake and digestion by sheep fed acacia-based diets. Four diets were tested according to a $4 \times 4$ Latin square design on rumen fistulated sheep (initial liveweight $47 \mathrm{~kg}$ ). All diets included airdried acacia leaves ad libitum, $176 \mathrm{~g}$ DM barley, $30 \mathrm{~g}$ mineral and vitamin supplement (control, D1) and supplemented with $15 \mathrm{~g}$ urea (D2), or $300 \mathrm{~g}$ DM cactus (D3), or $15 \mathrm{~g}$ urea and $300 \mathrm{~g}$ DM cactus (D4). Each experimental period lasted 25 days (15 days for adaptation and 10 days for measurements). Diet digestibility was measured by total faecal collection technique. Rumen fluid was sampled before morning meal and thereafter at 2, 4 and $8 \mathrm{~h}$ and analysed for $\mathrm{pH}$, ammonia nitrogen $\left(\mathrm{N}-\mathrm{NH}_{3}\right)$, and volatile fatty acids (VFA). Acacia degradability in the rumen was measured by the nyion bag technique (Ørskov et al, 1980, Trop Anim Prod, 5, 195213). Two grams samples of acacia (dried at $50^{\circ} \mathrm{C}$ and ground to pass through $3 \mathrm{~mm}$ screen) were introduced in nylon bags $(6.5 \mathrm{~cm} \times 9 \mathrm{~cm}$, pore size $50 \mu \mathrm{m})$. DM and nitrogen

Diets

D1

DM intake ( $\mathrm{g} / \mathrm{kg}$ LW0.75)

acacia

diet

Acacia/diet $(\%)$

Diet digestibility $(\%)$

$\mathrm{OM}$

CP

CF

Digestible OM intake ( $\mathrm{g} / \mathrm{kg} \mathrm{LW}^{0.75}$ )

Rumen parameters

$\mathrm{pH}$

$\mathrm{N}-\mathrm{NH}_{3}(\mathrm{mg} / 100 \mathrm{ml})$

Total VFA $(\mathrm{mmol} / \mathrm{l})$

$\mathrm{C}_{2} / \mathrm{C}_{3}$

In sacco degradability of acacia $(a+b, \%)$

dry matter

nitrogen $35.2^{\mathrm{ab}}$

$46.0 \mathrm{c}$

76.5

51.0

$31.9^{\circ}$

28.3

21. ${ }^{\mathrm{c}}$

6.86

$8.7^{b}$

$62.0^{\mathrm{b}}$

$6.0^{\mathrm{a}}$

47.0

24.4

disappearance rates of incubated acacia were fitted against incubation times $(4,8,16,24,48$, 72 and $96 \mathrm{~h}$ ) by the model of $\varnothing$ rskov and McDonald (1979, J Agric Sci, 92, 499-503).

Voluntary intake of acacia is low for all diets. It was not affected by urea supply (D2) but tended to decrease with cactus supply (D3). Highest intake of acacia was recorded with D4. Diet digestibilities of $O M$ and $C F$ were not significantly different ( $P>0.05$ ). As expected, CP digestibility of the diet increased by urea supply. Digestible OM intake for D1 was lower than the reported value needed for adult sheep (liveweight, $40 \mathrm{~kg}$ ) maintenance $(23 \mathrm{~g} / \mathrm{kg} \mathrm{LW} 0.75$; INRA, 1978). It was not affected by urea supply (D2) but increased when cactus was supplied alone (D3) or with urea (D4). Such increases may be explained by the low proportions of acacia in the diets associated with increases of total DM intakes. Urea supply (D2 and D4) resulted in an increase of $\mathrm{N}-\mathrm{NH}_{3}$ concentrations in the rumen fluid but did not affect neither the $\mathrm{pH}$ nor microbial activity measured by VFA concentrations and in sacco degradability of acacia. Likewise cactus supply (D3) did not affect the microbial activity.

It can be concluded that neither cactus (source of energy) nor urea (source of nitrogen) is an efficient supplement for improving the nutritive value of Acacia cyanophylla Lindl. leaves.

$\begin{array}{llll}\mathrm{D} 2 & \mathrm{D} 3 & \mathrm{D} 4 & \end{array}$

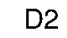

$35.0^{\mathrm{ab}}$

$45.8^{\mathrm{c}}$

76.4

52.9

$52.5^{a}$

32.7

$21.5^{c}$

6.82

$13.3^{3}$

$61.1^{\mathrm{b}}$

$5.4^{\mathrm{a}}$

45.0

28.7 $29.0^{b}$

$57.3^{b}$

50.6

53.8

39.1

27.8

$26.2^{\mathrm{b}}$

6.86

$6.1 \mathrm{~b}$

$66.1^{\circ}$

$3.4^{\mathrm{b}}$

47.5

30.1 $40.2^{a}$

$68.3^{a}$

58.8

54.4

$43.3^{\circ}$

32.5

$31.7^{a}$

6.81

$15.3 a$

$83.8^{\mathrm{a}}$

$4.0^{\mathrm{b}}$

48.9

32.7
1.1

1.1

0.7

2.4

2.0

0.62

0.01

0.6

2.5

0.1

1.3

1.2

a. b. $c$ : data in the same line with different superscripts differ $(P<0.05)$ 